\title{
Initial research for passive and energy efficient building awareness in Bulgaria
}

\author{
Veneta Yosifova ${ }^{1, *}$, Rosen Petrov $^{1}$, and Milena Haralampieva ${ }^{1}$ \\ ${ }^{1}$ Institute of Information and Communication Technologies, bl. 2, ac. G. Bonchev str.1113 Sofia, Bulgaria
}

\begin{abstract}
The paper observes the newest innovative technologies regarding buildings energy efficiency like passive building and smart home technologies. The market situation in Europe and in Bulgaria for these types of technologies is analyzed. The outcome of the research will serve as a milestone in developing of a methodology for determining Bulgarian society's awareness and attitude towards their using in home, business and production buildings.
\end{abstract}

\section{Introduction}

Energy efficiency is one of the most relevant topics in the modern society in order to reduce environmental impact and climate changes. Building sector consume more than $40 \%$ of the used energy worldwide, thus it is priority to decrease the energy devour and make the living more sustainable. Despite the EU regulations and government efforts, buildings energy efficiency is not a widespread topic in Bulgaria, and the population doesn't undertake enough measures for improving the energy consumption culture.

\section{Passive building essentials}

A passive building is the one that has comfortable inside climate, achieved without active working heating and cooling systems. It has the ability to heat and cool itself therefore it is called "passive". [1] (Fig. 1)

The building should be designed to be energy-efficient with minimum power for heating and cooling and to match specific requirements for maintaining pleasant ambience, high air quality and healthy environment. [2] (Fig.2)

There are few main objectives that the passive building should fulfill:

- The specific need for outside heating and cooling for a year shouldn't exceed $15 \mathrm{kWh} / \mathrm{m}^{2}$

- The total building consummation for all needs for a year shouldn't increase $120 \mathrm{kWh} / \mathrm{m}^{2}$

- The total renewable energy for all domestic applications for a year must not exceed $60 \mathrm{kWh} / \mathrm{m}^{2}$

- The airtightness should be less than 0,6 of building's volume with a pressure of $50 \mathrm{~Pa}$

- The temperature in all living spaces should be around $25^{\circ} \mathrm{C}$ with not more than $10 \%$ margin [3]
For achieving these objectives the designing phase should include some crucial points for construction:

- Compact shape and good insulation - the surrounding construction should be insulated with thermal transmittance (U-value) $<0.15 \mathrm{~W} /\left(\mathrm{m}^{2} \mathrm{~K}\right)$.

- South building orientation and shading avoiding Using suns passive energy is really important for achieving the main objectives.

- Energy efficient windows - Both glazing and frame profiles should guarantee U-value lower than $0.8 \mathrm{~W} /\left(\mathrm{m}^{2} \mathrm{~K}\right)$ and at least $50 \%$ sun gaining.

- Lack of thermal bridges - Air infiltration true bad insulated joints hourly shouldn't exceed 0,6 times building's volume.

- Passive advance heating/cooling — Fresh air in the building can be distributed true ground pipe systems, which transmit heat with the soil, that can heat up the air to $5^{\circ} \mathrm{C}$ even on the coldest days.

- Ventilation heat recovery - Efficient heat recovery ventilation empower good indoor air quality and energy saving By heat exchanger at least $80 \%$ of the heat from the exhaust air is transferred again to fresh air.

- Water heating - With solar panels and thermal pumps water heating becomes energy-efficient.

- Energy-efficient appliances - Preferable all home appliances and electronics should be with a high energy-efficient class. More preferably they should be connected altogether with SHTs panel. [1]

* Corresponding author: v.christova@gmail.com 


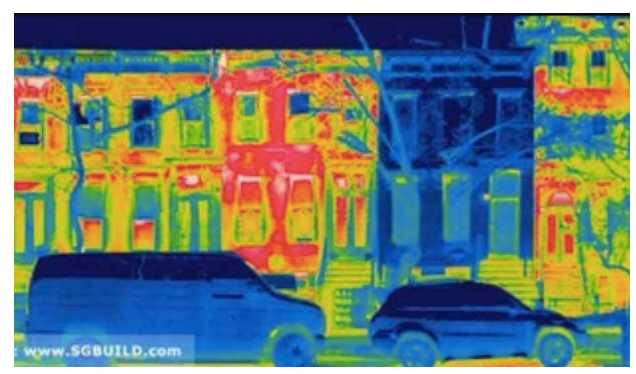

Fig 1. Thermal image of renovated to passive standards house next to neighbors without renovation (Photo: Sam McAfee of SGBuild)

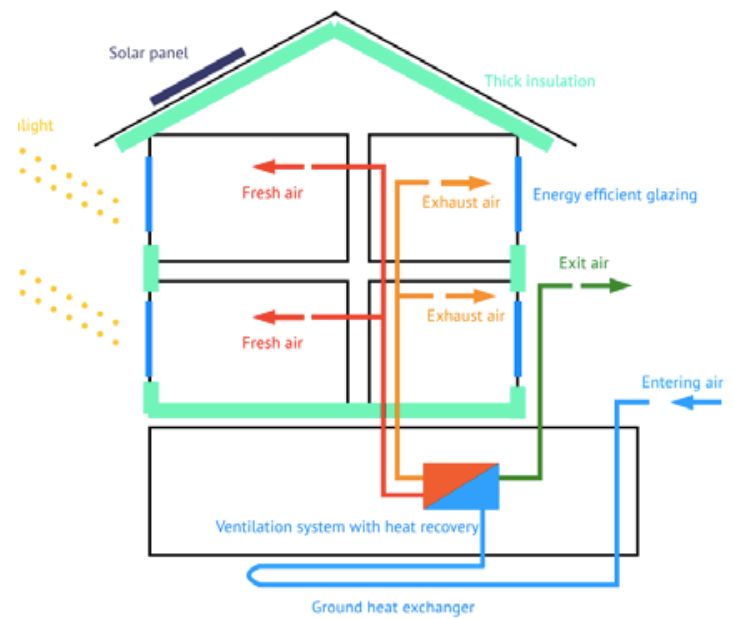

Fig.2. Passive house scheme

\section{Innovative technologies for passive buildings}

The international researchers and engineers are continuously working together to provide innovative energy efficient solutions in civil engineering in order to decreese energy consumption and reinvent the environmental way of living not only for home, but also for the business and production buildings. There are many examples of projects for buildings with nearly zero energy consumption, ones that even produce and supply their own energy.

\subsection{Dynamic tower (Dubai)}

According to the architectural firm Dynamic Group a rotating skyscraper is set for Dubai by 2020 (Fig. 3).

The 80-storey Dynamic Tower will be the world's first skyscraper made up of separate rotating floors attached to a central column and up to 90 percent of the tower, excluding the central column, could be built in a factory and then shipped to the construction site. The project is proposed in 2008 with intentions to be the third tallest building in Dubai, after the Burj Khalifa (828m) and Marina $101(432 \mathrm{~m})$. The Dynamic Tower will also generate its own energy through 79 wind turbines placed between each floor, as well as solar paneling that will coat both the roof of the building and the roof of each level. [4]

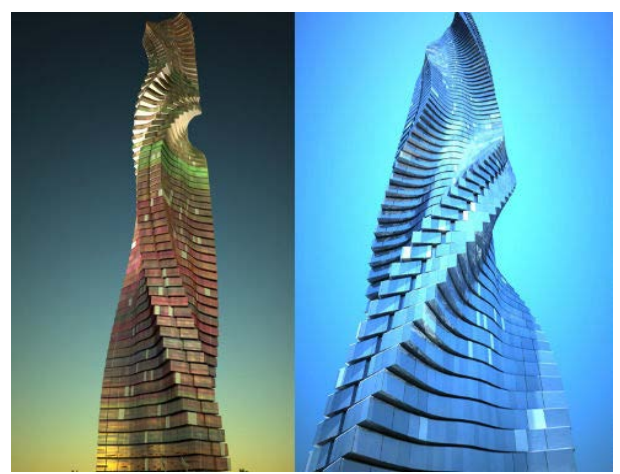

Fig. 3. Dynamic Tower Dubai

\subsection{0 on the Park (Chicago)}

With its 62-story height and residential use, 340 on the Park stands out as a major achievement in energy and environmentally conscious design. The building's architecture aims in maximum clear view to the surrounding area. Residents may also enjoy the winter garden located on the 25 th floor.

Despite the restrictions in sustainable design for residential building for systems like solar energy, wind driven turbines, the designers successfully implemented efficient techniques for environmental living like the use of recycled materials both for construction and maintenance, highly reflective white surface or green roof garden, internal storm water collection system, highly efficient envelope system, waste recycling process (for recycling over $82 \%$ of the produced waste). The result is a building that fits into the environmentally conscious standards and city's landscape. [5]

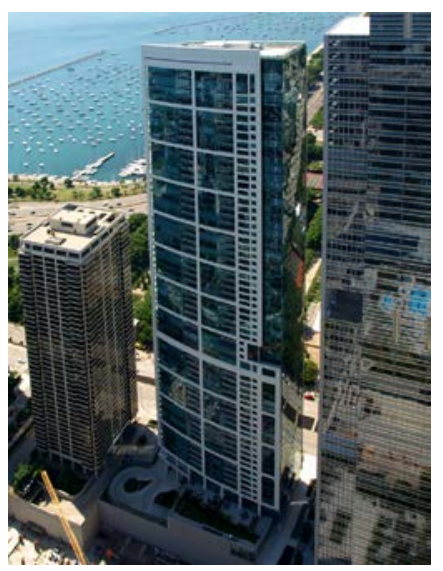

Fig. 4. 340 on the Park

\subsection{Smart home technologies (SHTs)}

For achieving even better energy results after building, it is preferable a building management system (BMS) or Smart home technologies (SHTs) to be integrated. Smart home technologies are jointly networking devises like sensors, monitors, interfaces or appliances that can enable automation, localize and control remotely the domestic environment. The devices that can be controlled include boilers and radiators for heating 
water, washing machines, lighting appliances, windows, curtains, garage doors, fridges, TVs, security systems etc. The environmental factors such as temperature, light, motion, and humidity are detected with sensors and monitors and their functionality is controlled by software on computing devices like smartphones, tablets, laptops, PCs or through configured hardware interfaces (wallmounted controls). Usually the smart home systems are networking wirelessly by standardized communication protocols. The configurations may vary depending of the software, the appliances, and the building's design. [6]

\section{Market situation in Europe and tendencies}

Over a period of two decades energy consumption in Europe has increased by more than $20 \%$ and the coil and oil production has dropped down significantly. Due to this factors more than $50 \%$ of the fossil fuels are imported, which means that the region isn't energyindependent. Many public questions have raised, concerning global trade, climate impact and energy security.

The capacity in the region for providing renewable energy is limited and influenced by geographical location, climate and geology. The economical factor also is important, taking in consideration the poorer countries. This means that the measures for increasing the energy efficiency in new and existing buildings is important for the future energy use and the renewable sources of energy like the solar radiation, wind and water power has to be put efficiently in use. [7]

According to EDJNet (The European Data Journalism Network) research, millions of Europeans can't heat well their homes in the winter. But energy poverty in households is also a problem in the summer, especially in Southern and Eastern Europe. Sweden, Finland and Denmark, Austria, Luxemburg has the best energy poverty indicators, which can be explained with their strict construction standards and better social support for the poor households. [8]

The Energy Efficiency Directive from 2012 establishes a set of binding measures to help the EU reach $20 \%$ energy efficiency target by 2020 . Under the Directive, all EU countries are required to use energy more efficiently at all stages of the energy chain, from production to final consumption.

On 30 November 2016 the Commission proposed an update to the Energy Efficiency Directive, including a new 30\% energy efficiency target for 2030, and measures to update the Directive to make sure the new target is met.

The specific measures that could be taken into consideration include:

- Improving the efficiency of heating systems, installing double-glazed windows or insulating roofs.

- Building energy efficient buildings, products and services.

- Governments in EU countries must carry out energy efficient renovations on at least $3 \%$ (by floor area) of the buildings they own and occupy.
- The consumers should be empowered to better manage consumption.

- Providing audits of large companies energy consumption for identification and future reduction [9] One of the EU's 10 priority action areas in its Strategic Energy Technology Plan is the smart home. The sales are increasing both off-the-shelf and with professional installation. However the demand in general is still low, and smart product sales are dominated by smart TVs. Because of the fear of security issues SHT developers are already recognizing the challenge of gaining the trust and confidence of prospective users.

Several studies have examined prospective users concerns about SHTs in more depth using small samples in technology demonstration labs, deliberative workshops, or focus groups. These studies have confirmed interest in the energy management potential of smart homes, but have also identified potential market barriers to adoption including cost, privacy, security, reliability, and the interoperability of different technologies. A wider set of sociotechnical concerns with SHTs includes an increased dependence on technology, electricity networks or outside experts, and the proliferation of non-essential luxuries inducing laziness in domestic life. [6] This will indicate the need of multiple presentations, marketing activities, workshops and exhibitions in order to achieve wider awareness and spreading detailed information about the products and the services and the benefits of using.

\section{Building's energy efficiency in Bulgaria}

According to NSI (National Statistic Institute) in Bulgaria, the main energy source is coal, oil and petroleum products, along with nuclear energy and natural gas. [10]

However the country has good energy performance compared with the other EU countries and has efficiently implemented good practices in using renewable energy resources with a potential of growth.[11]

Bulgaria has significant potential for implementing energy efficiency measures. Increasing energy efficiency will contribute to limiting carbon dioxide and other greenhouse gas emissions and will therefore help to prevent climate change.

The National Energy Efficiency Action Plan sets indicative national targets for energy savings by 2020:

Energy savings in Final energy consumption (FEC) $-716 \mathrm{rpm}$.

Energy savings in Primary energy consumption (PEC) - $1590 \mathrm{rpm}$, of which $169 \mathrm{rpm}$. in power conversion, transmission and distribution processes.

The additional energy savings in the FEC are determined by the implementation of a strong energy efficiency policy and the optimal utilization of additional financial resources available from different sources like European funds and programs, national budged, local sources etc.

The building sector is determined as the biggest energy consumer and the energy consumption is 
continuing to grow due to increased economic activity, changes in productivity, climate effect, changes in consumer behavior and other.

Some of the measures in the building sector are related to mandatory building certification, labeling the electrical appliances, procedures for distributing of heat shares in multifamily homes, etc.

The financial measures introduced in the sector include expanding the administrative, functional and financial capacity of the Energy Efficiency and Renewable Sources Fund in order to finance projects concerned to renewable energy, as well as increasing grants for energy efficiency measures in households.

Another measure with a big impact is the National Energy Efficiency Program in multifamily residential buildings. The program aims at renovating multifamily residential buildings by introducing energy-saving measures to improve the thermal comfort and thus - the living environment and the quality of life of the residents in the buildings. [10]

Despite the active national measures, some effective means as the passive homes/buildings and implementing new technologies hasn't been taken in consideration as leverage for increasing the energy efficiency so far. Such kind of building is not so popular as in the western countries, although it has a huge influence in reducing energy consumption and environmental impact. One of the main reasons for that is the high initial cost.

Building component's high quality and excellent characteristics influence the high price. Multiple researches shows that in Europe (with more than 25000 passive buildings) the average cost is increased with 10$15 \%$. In Bulgaria this increasing is higher since the quality of the included materials in usual building is lower compared to the European standards. Even so, in long-term perspective, the capital invested is regain due to the energy and repairmen savings. [12]

\section{Existing objects in Bulgaria}

Because of the new methodology and the lack of practical knowledge, the Passive house Standard is not so popular in the country and the region. There are only few finished projects that combine the innovative thinking, visionary building approach and technical progress under one roof. Some of them serve as an example, that passive building is possible in the region and brings only benefits in terms of energy savings as listed in the table of building's PHPP (Passive House Planning Package) values (Table 1). Despite the fact that there are several main companies on the market, there isn't much data of how many houses are using SHT modules, since most of them don't fully reveal their client and project cases.

\subsection{Residential house in Varna}

This is the first passive house in Bulgaria (Fig. 5). It has two floors, build by innovative module system according to "Passive Home" standard. Along with the great energy and economical efficiency, it has sound insulation, fire proof, seismic calculation and high quality of construction. The main difference from the regular building is the healthy and comfort microclimate. The most significant quality is the energy independence. [13]

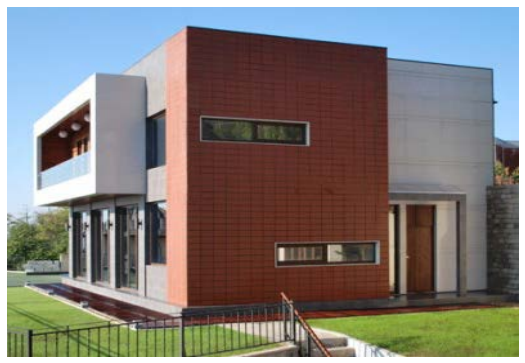

Fig. 5. Residential house in Varna (Photo by Megamat Ltd.)

\subsection{Residential house in Kladnitsa}

The house is build by the Passive house standard on the slopes of Vitosha Mountain (Fig. 6). The area is large $(970 \mathrm{~m} 2)$ which was a challenge to fit into the local natural environment. The structure is light and ecofriendly. Because of the roof-mounted photovoltaic collectors the house will generate more energy than it consumes. The collected energy will be used in the household and the overage will be sent to the electrical network. [14]

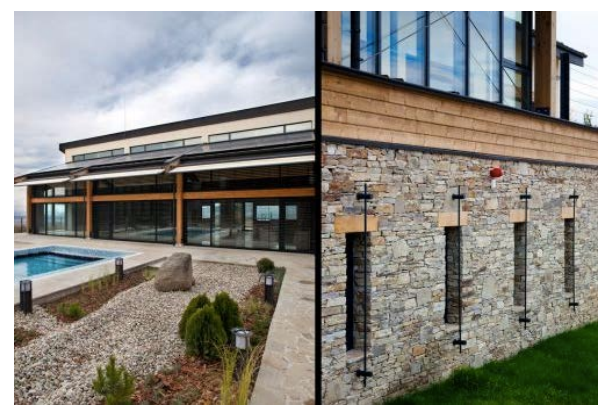

Fig.6. Residential house in Kladnitsa (Photo by Arxe Ltd.)

\subsection{Residential house in Voinegovtzi}

The house is located on the southern slopes of Stara Planina, with natural surrounding and great city view (Fig.7). Because of the passive House Standard the building combine profitability, comfort and the environmental friendliness altogether. The house is built with Bulgarian materials and its main idea is to be an example of the passive home possibilities. [15] 


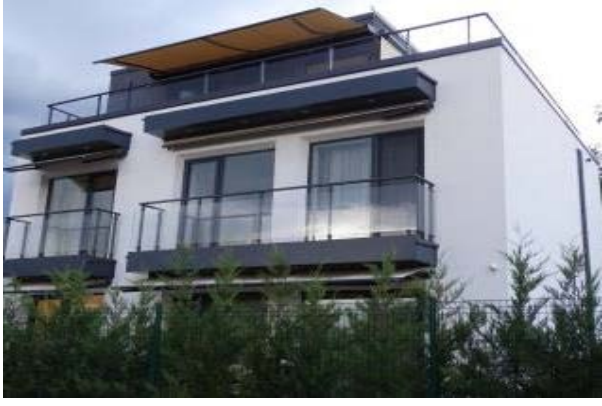

Fig. 7. Residential house in Voinegovtzi (Photo by Passive House Bulgaria Ltd.)

Table 1: Passive house characteristics

\begin{tabular}{|c|c|c|c|}
\hline Location & Varna & Kladnitsa & Voinegovtzi \\
\hline $\begin{array}{l}\text { Year of } \\
\text { building }\end{array}$ & 2009 & 2013 & 2016 \\
\hline $\begin{array}{l}\text { Type of } \\
\text { building }\end{array}$ & Residential & Residential & Residential \\
\hline $\begin{array}{l}\text { Type of } \\
\text { construction }\end{array}$ & Steel & Mixed & Masonry \\
\hline $\begin{array}{l}\text { Design/Builder } \\
\text { Ltd. }\end{array}$ & Megamat & $\begin{array}{l}\text { Apxe } \\
\text { Studio }\end{array}$ & $\begin{array}{l}\text { Eco } \\
\text { Construction }\end{array}$ \\
\hline \multicolumn{4}{|l|}{ PHPP values } \\
\hline $\begin{array}{l}\text { Annual } \\
\text { heating } \\
\text { demand } \\
{[\mathrm{kWh} / \mathrm{m} 2 \text { a] }}\end{array}$ & 13 & 15 & 12 \\
\hline $\begin{array}{l}\text { Primary } \\
\text { energy } \\
\text { requirement [k } \\
\mathrm{Wh} / \mathrm{m}^{2} \text { a] }\end{array}$ & 57 & 39 & 88 \\
\hline $\begin{array}{l}\text { Air tightness } \\
\text { n50 [h-1] }\end{array}$ & 0,5 & 0,13 & 0,2 \\
\hline $\begin{array}{l}\text { Heating load } \\
{\left[\mathrm{W} / \mathrm{m}^{2}\right]}\end{array}$ & 14 & 14 & 12 \\
\hline $\begin{array}{l}\text { Cooling load } \\
{\left[\mathrm{W} / \mathrm{m}^{2}\right]}\end{array}$ & 4 & 2 & 8 \\
\hline
\end{tabular}

\section{Conclusion}

Bulgaria is trying to keep up with the EU practices concerning building's energy efficiency. The science and the building sector work hand in hand in order to develop innovative technologies for reducing energy consummation and sustainable exploitation of the natural resources. Passive buildings and smart home technologies are already renovating Europe's civil engineering and have the potential to become a must in Bulgarian market as well. Although not so popular on the Balkans, these practices are very suitable for the region, because of the appropriate seasons and landscape. The architectural studios and building companies are already making progress in implementing them in the sector, but the benefit awareness is not so spread across the end consumers. In order to gain citizens attention into the most innovative tendencies in building's energy efficiency, an initial survey will be conducted for summarizing people's mindset, expectations and concerns. The results will assist in further analysis of how the energy efficiency opportunities in Bulgarian home, business and production buildings can be promoted to the wider audience for ensuring cost effectiveness, environmentally friendly life and sustainable future in the country and further more in the region.

Acknowledgments: This article is supported by the Bulgarian Ministry of Education and Science under the National Research Programme "Young scientists and postdoctoral students" approved by DCM \# 577 / 17.08.2018

\section{References:}

1. Arch. G. Nikolov, What is a "Passive" Building?, http://www.passive.bg

2. B. Eldredge, Passive house construction: Everything you need to know, (2016) https://www.curbed.com

3. Passive Home Institute, Passive House requirements, https://passiv.de

4. A shape-shifting, rotating skyscraper is set for Dubai by 2020 , http://whatson.ae

5. 340 on the Park, Council on Tall Buildings and Urban Habitat, http://www.skyscrapercenter.com

6. C. Wilson, T. Hargreavesb, R. Hauxwell-Baldwinb, Benefits and risks of smart home technologies, Energy Policy 103 (2017) 72-83

7. S. Stremke, J. Koh, Energy-Conscious Regional Design: Synergy between Ecosystem Thinking and Spatial Planning, PLEA (2008)

8. Bulgaria has the worst indicators of energy poverty, https://news.bg

9. Energy Efficiency Directive (2012/27/EU) of the European Parliament

10. Agency for Sustainable Energy Development, Energy Efficiency Trends and Policies in Bulgaria (2018)

11. Eurostat, Renewable energy in the EU Share of renewable energy in the EU up to $17.5 \%$ in 2017 , press release (2019)

12. Arch. D. Popdimitrov, What is a Passive House?, Architectural Agency GRID GRAFIKS BG, https://www.apхитект.bg

13. Passive Buildings Bulgaria, Passive Family House, http://www.passive.bg

14. Passive Buildings Bulgaria, Plus energy passive house, www.passive.bg

15. Passive House Database, https://passivehousedatabase.org 